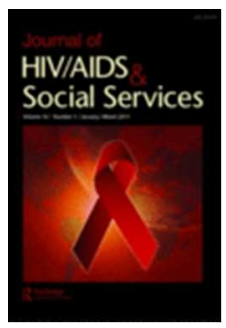

\title{
In What Ways do Religious Congregations Address HIV? Examining Predictors of Different Types of Congregational HIV Activities
}

\begin{tabular}{|c|c|}
\hline Journal: & Journal of HIV/AIDS \& Social Services \\
\hline Manuscript ID & WHIV-2017-0036.R1 \\
\hline Manuscript Type: & Research and Practice Article \\
\hline Keywords: & $\begin{array}{l}\text { HIV/AIDS health promotion < Service Practices, faith-based organizations } \\
<\text { Service Practices, HIV prevention < HIV/AIDS Transmission \&/or Risk, } \\
\text { HIV awareness, HIV/AIDS support, health care disparities < Underserved } \\
\text { Populations }\end{array}$ \\
\hline Abstract: & $\begin{array}{l}\text { Religious congregations play an important role in HIV prevention and care. } \\
\text { However, most research on congregation-based HIV activities has focused } \\
\text { on prevention. Using data from a nationally representative survey of U.S. } \\
\text { congregations, we found that } 18.6 \% \text { of congregations were engaged in } \\
\text { some type of HIV activity; } 8.7 \% \text { engaged in prevention; } 7.6 \% \text { offered } \\
\text { support to people with HIV; } 7.4 \% \text { raised awareness; and } 7.6 \% \text { provided } \\
\text { donations for other organizations' HIV activities. Among congregations that } \\
\text { participate in some type of HIV activities, having more educated clergy is } \\
\text { associated with higher odds of engaging in support, raising awareness, and } \\
\text { giving donations relative to prevention activities. Being a predominantly } \\
\text { African-American congregation is associated with lower odds of these the } \\
\text { other three types of HIV activities compared to prevention } \\
\text { activities. Understanding the factors associated with specific types of HIV } \\
\text { activities helps inform policy and practice related to congregation-based } \\
\text { HIV programming. }\end{array}$ \\
\hline
\end{tabular}

\section{SCHOLARONE ${ }^{\text {m }}$ \\ Manuscripts}


Predictors of Congregational HIV Activities

In What Ways do Religious Congregations Address HIV? Examining Predictors of Different Types of Congregational HIV Activities 
Predictors of Congregational HIV Activities

\begin{abstract}
Religious congregations play an important role in HIV prevention and care. However, most research on congregation-based HIV activities has focused on prevention. Using data from a nationally representative survey of U.S. congregations, we found that $18.6 \%$ of congregations were engaged in some type of HIV activity; $8.7 \%$ engaged in prevention; $7.6 \%$ offered support to people with HIV; $7.4 \%$ raised awareness; and 7.6\% provided donations for other organizations' HIV activities. Among congregations that participate in some type of HIV activities, having more educated clergy is associated with higher odds of engaging in support, raising awareness, and giving donations relative to prevention activities. Being a predominantly AfricanAmerican congregation is associated with lower odds of these the other three types of HIV activities compared to prevention activities. Understanding the factors associated with specific types of HIV activities helps inform policy and practice related to congregation-based HIV programming.
\end{abstract}

\title{
Keywords: HIVIAIDS health promotion, Faith-based organizations, HIV prevention, HIV awareness, HIVIAIDS support, Health care disparities
}


Predictors of Congregational HIV Activities

\section{INTRODUCTION}

Despite advances in treatment, HIV is a leading cause of U.S. mortality and morbidity. An estimated 1.1 million people are now infected, with 21 percent unaware of their infection because they have not been tested (CDC, 2011). African Americans bear a heavy burden. For example, although they comprise only about 13 percent of the U.S. population, they account for almost half of all existing and new HIV cases (CDC, 2011). Addressing HIV requires developing solutions for both health care and community-based settings. Faith-based organizations such as religious congregations are uniquely positioned to address HIV within community settings. Congregations are credible, stable entities that provide empowerment and support and promote health among members and, thus, may be uniquely positioned to address HIV. Religious congregations have complex social networks that can be leveraged for health promotion and to disseminate information about community problems and resources (Young, Shoptaw, Weiss, Munjas, \& Gorbach, 2011). Congregations also provide access to such resources as informal support, food, health care, and educational and job opportunities through extended social networks and linkages with other community institutions (CDC, 2011; Redacted, 2016; Kaiser Family Foundation, 2006). Previous research has shown that religious organizations can promote health and well-being, both within their congregations and through outreach to the community (Campbell et al., 2007; DeHaven, Hunter, Wilder, Walton, \& Berry, 2004; Maton \& Rappaport, 1984). Moreover, congregations have access to and experience in addressing the needs of disadvantaged and high-risk populations who may be adversely impacted by HIV, particularly African-American congregations. African Americans, and AfricanAmerican women in particular, are more likely to self-identify as religious than the general population (Boltri et al., 2006; Maton \& Rappaport, 1984) and African-American congregations have demonstrated capacity to provide health and social services support to their communities (Blank, Mahmood, Fox, \& Guterbock, 2002)

Despite congregational assets that could be leveraged for addressing HIV, recent analyses have shown that a substantially smaller proportion of congregations $(5.7 \%)$ have developed HIV programs than other types of health programs (57.5\%) (Redacted et al., 2015). It is not clearly understood why relatively few congregations engage in HIV activities but a growing literature on this topic suggests that the factors positively related to congregational HIV activities include the congregation's perceived need to address HIV (Chin, Mantell, Weiss, Bhagavan, \& Luo, 2005; Redacted et al., 2010; Hernandez, Burwell, \& Smith, 2007; Hicks, 
Predictors of Congregational HIV Activities

Allen, \& Wright, 2005); engaging in a process to assess community needs (Redacted et al., 2015); pastor

knowledge about HIV or experience developing such programs(M. Chaves \& Tsitsos, 2001; Tesoriero et al., 2000; Thomas, Quinn, Billingsley, \& Caldwell, 1994); greater resources including congregation size, staffing and budgets(Frenk \& Trinitapoli, 2012; Hernández, Burwell, \& Smith, 2007; Smith, Simmons, \& Mayer, 2005; Tesoriero et al., 2000; Redacted et al., 2015); the race or ethnicity of the congregation (Frenk \& Trinitapoli, 2012; Redacted , 2011; Redacted et al., 2015) and being engaged in external collaborations (Chin et al., 2005; Redacted et al., 2015). On the other hand, HIV-related stigma (Chin et al., 2005; Leong, 2006) associated with male-to-male sex, substance use, and extramarital sex may also make congregations reluctant to address HIV (Chin et al., 2005; Leong, 2006; Thomas et al., 1994). In addition, Redacted and colleagues (2015) found that the factors associated with congregational HIV activities differed by size of congregation with only the existence of a statement welcoming gay persons being associated with HIV activities in congregations of all size categories (Redacted et al., 2015).

One gap in the literature on congregational involvement in HIV activities is that much of the current research focuses on congregational HIV prevention activities (Coleman, Lindley, Annang, Saunders, \& Gaddist, 2012; Redacted et al., 2011; Francis \& Liverpool, 2009; Obong'o, Pichon, Powell, \& Williams, 2016; Tesoriero et al., 2000). But in-depth, case study research conducted by Redacted and colleagues (Redacted et al., 2011) has identified a continuum of activities that congregations have implemented, including: care and $\underline{\text { support activities such as pastoral care or support of other organizations serving people with HIV; awareness }}$ and advocacy such as congregational members participating in an AIDS Walk; and prevention and education activities such as HIV education provided as part of a workshop (Redacted et al., 2011). It is not known how the factors associated with the existence of congregation-based HIV activities in general are associated with these various types of HIV activities. Moreover, our understanding of the relative prevalence of the various types of HIV activities identified by Redacted and colleagues has been limited by a lack of data.

Recent waves of the National Congregations Study (NCS), which is a nationally representative study of religious congregations in the U.S., have begun to address this data gap. With the 2006-2007 wave, HIV activities were identified by a response to the following question: "Does your congregation currently have any program or activity specifically intended to serve persons with HIV or AIDS?" Although this question was an 
Predictors of Congregational HIV Activities

improvement over the 1998 wave, where the only way to identify HIV activities was through coding open-ended responses to a question about congregational programs in general, it is not clear the extent to which this question identified programs that included HIV prevention and education activities, care and support activities, or awareness and advocacy activities. Moreover, while previous research has identified factors related to congregational HIV activities, little is known about the specific types of HIV activities in which congregations engage or how much these vary across congregations and communities.

To gain more specificity and a better understanding of congregational HIV activities, we translated earlier qualitative findings into specific items that were included in the latest wave (2012) of the NCS. These new items allow for a much more nuanced analysis of the types of HIV activities that congregations conduct and the factors associated with these activities by distinguishing among activities that support people living with HIV (PLWH), those that prevent HIV transmission (including testing), and those that raise awareness about HIV in the broader community. Another item asks about financial or in-kind donations to other organizations addressing HIV. Thus, this study aimed to examine the prevalence of these various types of HIV activities and to assess whether there are systematic differences in predictors of these different types of activities.

For our study, we drew on frameworks developed by Redacted and colleagues (Redacted et al., 2010) and Redacted and colleagues (Redacted et al., 2015; Redacted, Palar, \& Redacted, 2011) to conceptualize why and how congregations implement HIV prevention and care activities. Specifically, we have identified four domains or sets of characteristics that may predict how congregations address HIV in their communities.

1. Congregational composition and community context, which encompass congregational norms and beliefs, including specific attitudes about whether congregation-based HIV activities are needed (Chin et al., 2005; Redacted et al., 2010; Hicks et al., 2005), as well as congregational and community demographic and health characteristics that may inform these attitudes. For example, this domain encompasses characteristics such as pastor education which is thought to be associated with HIV activities in general.

2. Congregational doctrine and policy includes a congregation's theological or political orientation (i.e., conservative, liberal). These orientations can affect whether the congregation engages in any type of social service or health activities and how the congregation might address HIV. Doctrine and policy may 
Predictors of Congregational HIV Activities

also affect congregational attitudes toward persons who are at risk for HIV or who have the disease.

Stigma is particularly important; as Chin and colleagues (Chin et al., 2005) note, religious organizations often experience a tension between wanting to address HIV and struggling with their beliefs about the morality of homosexuality, drug use, and the disease itself.

3. Congregational resources may determine the extent to which congregations can get engaged in these activities (Nohria \& Gulati, 1996; Rogers, Doinolngersoll, HayesCozier, \& Weisfuse, 1996; R. H. Rubin, Billingsley, \& Caldwell, 1994; Tesoriero et al., 2000; Thomas et al., 1994; Tsitsos, 2003). For example, congregations with few resources may be less likely to engage in costlier activities such as donating to other organizations or coordinating more complicated information campaigns.

4. External engagement of the congregation describes how congregations may develop relationships with other organizations and how these interactions affect the development of HIV activities. External organizations provide resources and information to increase capacity for implementation. Once again, it is not clear whether externally-reaching congregations are more likely to engage in certain types of congregational HIV activities such as donating to other organizations or raising awareness about HIV.

In the analyses described herein, we test whether there is an association between the variables in each of these domains with the existence of any type of HIV activity and the four different types of HIV activities specifically. Clarifying how predictors of specific types of HIV activities differ from one another may provide insights into how congregations choose among potential HIV prevention and care strategies. Further, this information may help public health and social service agencies identify specific types of congregations to engage or the types of activities on which to focus.

\section{METHODS}

\section{Sample}

We used data from the 2012 wave of the National Congregations Study (NCS) (M. Chaves, Anderson, \& Eagle, 2014; Mark Chaves \& Anderson, 2014), a nationally representative survey of congregations in the U.S. that collects a broad array of congregation characteristics, including data on congregants, congregation resources, and detailed information on congregation activities. Data were collected from key informants at 
Predictors of Congregational HIV Activities

1,331 congregations; $87 \%$ of congregations that were contacted agreed to participate. To control for community-level factors in our analysis, we merged county-level health status (measured as a composite of mortality and morbidity) from the 2012 Robert Wood Johnson Foundation (RWJF) County Health Rankings and 2010 HIV rate from AIDSVu, a compilation of statistics completed by the Rollins School of Public Health at Emory University (AIDSVu (www.aidsdvu.org)).

\section{Measures}

\section{Outcome variables}

Drawing from our earlier qualitative research (Redacted et al., 2011), we created four items measuring specific types of HIV-related activities that congregations engaged in within the past 12 months. The response options for each were yes or no:

- Within the past 12 months, have there been any groups or meetings or classes or events specifically focused on...

- Providing support, such as food, housing, personal items, or pastoral care to persons living with HIV or AIDS? [Support]

- Preventing HIV transmission, such as teaching about prevention strategies or promoting HIV testing? [Prevention]

- Raising awareness about HIV in other ways, such as sponsoring World AIDS Day events or participating in an AIDS walk? [Awareness]

- Within the past 12 months, has your congregation given financial or in-kind donations to an organization whose primary purpose is to help people living with HIV or AIDS, or to prevent HIV transmission? [Donating]

Dichotomous variables were created for congregation involvement in each type of HIV activity. In addition, if a respondent responded 'yes' to at least one of these items, the congregation was coded as having "any HIV activity".

\section{Predictor variables}


Predictors of Congregational HIV Activities

We divided covariates into the four domains highlighted in our conceptual framework and that parallel our analyses of the 2006-2007 NCS data (Redacted et al., 2015).

Domain (1) congregational composition and community context, includes the core set of control variables for our analytic models: whether the congregation is located in an urban census tract, whether its census tract is considered high poverty with greater than $30 \%$ of residents living below the federal poverty line, HIV rate of the County, overall health index of the county, level of education of the pastor, proportion of congregants that are over age 60 and percent below age 35; length of time the congregation has existed, an indicator variable designated it as an African American congregation, and another indicating whether it is a Latino congregation. A congregation may be coded as both an African-American congregation and a Latino congregation. The remaining three domains represent areas of interest to this study.

Domain (2) congregational resources, includes annual expenditures, number of staff, number of adult attendees, and whether the congregation has a staff person that dedicates $25 \%$ of their time on service programs.

Domain (3) external engagement, includes indicator variables for whether the congregation assesses community need, collaborates with other organizations, participates in political activities, and seeks government funding.

Domain (4) doctrine and policy, includes indicator variables for whether the congregation is politically conservative, theologically conservative, believes the Bible is inerrant, allows gay members, allows gay leaders, has any openly HIV-positive members and has any openly gay participants.

Domains and variables are shown in Table I. All variables except the County Health Index and county HIV rates are included in the NCS dataset. We used the 2012 RWJF County Health Index to measure overall health outcomes in the community of each congregation. This index is a weighted mean of county-level measures of mortality (years of potential life lost before age 75) and morbidity (mean self-reported health status, mean number of physically and mentally unhealthy days per month, and percentage of live births with low birth weight). Higher values of the composite indicate worse health. We modified the RWJF algorithm so that each mortality and morbidity measure was standardized against all counties in the US rather than by state. 
Predictors of Congregational HIV Activities

We also included 2010 HIV rate per 1,000 county residents as compiled by AIDSVu. We filled in missing data for 10 counties by using contemporaneous state or local surveillance data.

\section{Analysis}

We weighted the sample to the attendee level for all analyses, which has been identified in prior analyses as being more appropriate for studies concerned with the social impact of congregational activity (M. Chaves, 2004; Redacted , 2011; Redacted et al., 2015; Wuthnow, 2004). This means that the data are viewed from the perspective of attenders at the average congregation (M. Chaves et al., 2014). With respect to congregation HIV activities this allows us to assess relative to the number of church attenders exposed to these activities rather than the number of congregations that support them. To determine which predictors are associated with having "any HIV activity" and which are associated with each type of HIV activity, we first modeled having "any HIV activity" and having each type of activity among all congregations using multivariate logistic models which controlled for all predictors shown in Table I. These models are presented in Table III.

Next, we explored which predictors were associated with specific types of HIV activities among congregations offering any such activity. Because congregations may offer more than one type of HIV activity, it is not adequate to simply compare logistic regression models for each outcome. Rather, we estimated these associations using an alternative-specific conditional logistic model of HIV activity type(s) on predictors (Table IV). This model estimates odds ratios for each of three outcomes (support activities, awareness activities, donating) relative to the reference outcome, prevention activities. Much of what is known about congregational HIV activities is based on studies in which HIV prevention is the primary outcome of interest (Redacted et al., 2011; Francis \& Liverpool, 2009; Tesoriero et al., 2000). We started with a full model that included all predictors in Table I, and then selected a reduced set of predictors in a sequential fashion to improve precision in our models. In the first stage, we reduce the full model by retaining only predictors that were significantly predictive of having any HIV activity $(\mathrm{p}<0.05)$ or were significantly or moderately significantly predictive of which type of HIV activity was offered $(p<0.20)$. In the second stage, we further dropped all predictors that did not meet the $p<0.20$ cutoff. 
Predictors of Congregational HIV Activities

Missing values and imputation

We multiply imputed missing data by using the Imputation by Chained Equations (ICE) package in Stata 13.1 (Royston, 2009). Results from 30 complete imputed datasets were pooled using Rubin combination rules (D. B. Rubin, 1987). We dropped congregations that were not geocoded $(n=3)$ or that were missing information on which types of HIV activities were offered $(n=22)$. Our analytic dataset contains 1,306 congregations, $98.1 \%$ of congregations in the sample.

\section{RESULTS}

Table II presents characteristics of congregations in the analytic sample, weighted to the attendee level. $26.5 \%$ of attendees attend a congregation that is engaged in at least one type of HIV activity (weighted to the congregation level, $18.6 \%$ of congregations are engaged in any type of HIV activity). Engagement levels for each type of HIV activity were approximately equal: $12.3 \%$ of attendees were in congregations that offered prevention activities (8.7\% of congregations), $11.9 \%$ of attendees were in congregations that offered support activities ( $7.6 \%$ of congregations), $12.3 \%$ of attendees were in congregations that offered awareness raising activities (7.4\% of congregations), and $12.4 \%$ of attendees were in congregations that provided donations to another organizations for their HIV activities (7.6\% of congregations).

\section{Attendee-level-weighted logistic models of offering any HIV activity and offering each type of HIV activity}

Table III summarizes weighted logistic models of having any HIV activity (column 1) and having each type of HIV activity (columns 2-5) among all congregations. Several factors were associated with offering an HIV activity in this analysis. Congregations were less likely to engage in HIV activities if senior clergy had some college or a 4-year degree compared to congregation with senior clergy with a high school degree or less $(\mathrm{OR}=0.42)$. Politically conservative congregations were also less likely to have an HIV activity $(\mathrm{OR}=0.62)$. Factors associated with a greater likelihood of having an HIV activity were: having a predominately AfricanAmerican congregation ( $O R=2.65$, compared with other congregations), having at least $25 \%$ of a staff 
Predictors of Congregational HIV Activities

member's time devoted to service activities $(O R=2.20)$, assessing community need $(O R=2.11)$, political participation (OR=1.53), and having an HIV-positive member $(\mathrm{OR}=2.50)$.

The second column of Table III shows that predictors of having an HIV prevention activity are similar to predictors of having any HIV activity. Clergy education beyond high school was associated with a lower likelihood of offering a prevention activity $(\mathrm{OR}=0.24$ for some college or a 4-year degree and 0.43 for a graduate degree, both compared with high school or less). Congregations were more likely to offer prevention activities if they were predominately African-American (OR=5.79), devoted at least $25 \%$ of a staff member's time service activities $(\mathrm{OR}=2.61)$, assessed community need $(\mathrm{OR}=2.41)$, or had an HIV-positive member $(\mathrm{OR}=2.19)$

Associations between predictors and having any HIV activity (column 1) versus having specific types of HIV activities (column 2-5) were similar, but differed for several variables. In contrast with prevention activities, clergy education beyond high school was not a significant predictor of the other three types of activities. African-American congregations were more likely to engage in all three other types of programming $(O R=2.81$ for support, 3.66 for awareness, and 3.46 for donation). Assessing community need was a significant predictor of support $(\mathrm{OR}=2.16)$ activities, but not awareness activities or donating. Two significant predictors overall, political participation and politically conservative, were only significant predictors of one type of activity, awareness (OR for political participation=2.14, OR for politically conservative=0.43).

Several predictor variables were not found to have a significant association with any HIV activity. These included: location in an urban or high poverty census tract, County HIV rate or health index, average age of congregants, longevity of the congregation, being a Latino congregation, annual expenditures, engaging in collaborations, seeking government funding, being theologically conservative, belief that the bible is inerrant, allowing gay members or leaders, and having openly gay participants.

\section{Alternative-specific conditional logistic model}

Table IV summarizes the reduced alternative specific conditional logistic model of which type(s) of activities are offered among congregations offering any HIV activity. The odds of having activities for support, awareness, and donation are each compared to the reference outcome group, prevention. The fourth column shows joint tests of equality across all outcome groups. 
Predictors of Congregational HIV Activities

Clergy education beyond high school is associated with higher odds of support, awareness, and donation rather than prevention. Predominately African-American congregations are more likely to engage in prevention activities compared with each of the other three activity types $(\mathrm{OR}=0.18$ for support, 0.29 for awareness, and 0.19 for donation). Under congregational resources, having more staff is associated with higher odds of donation compared with prevention programming $(\mathrm{OR}=1.27$, for a 1 standard deviation increase in number of staff). Politically conservative congregations are less likely to engage in awareness than prevention of HIV $(\mathrm{OR}=0.30)$. Relative to prevention, there was no evidence of an association between support, awareness, and donation and the following predictors: County HIV rate, proportion of adult participants aged less than 35, engaging in collaborations, or having an HIV positive member.

\section{DISCUSSION}

Our study examined specific types of HIV activities that congregations in the United States implement and which congregational and community characteristics are associated with each type of congregational HIV activity. We found that the prevalence of congregation-based HIV activities is substantially higher than that found in the $2006-2007$ wave (26.5\% of attendees in a congregation with some type of HIV activity in 2012 vs. $10.2 \%$ in a congregation with a program that supports people with HIV in 2006-2007). It is not clear, however, what portion of this increase is the result of more congregations addressing HIV and what portion is the result of greater comprehensiveness in the NCS items used to ascertain involvement in HIV activities. We also found that congregations are equally likely to engage in each of the four types of HIV activities about 12 percent across congregations for each type).

There were several factors that were consistently positively associated with each type of HIV activity: being a predominantly African American congregation, having a staff person with at least $25 \%$ time dedicated to supporting social service activities, and having an openly HIV positive person in the congregation. These factors are consistent with the prior literature (Redacted et al., 2015). African American congregations have a long history in social service engagement and are more likely than congregations of other racial-ethnic composition to engage in HIV activities. In addition, research on the NCS has found that having a staff person with dedicated time to support social services increases the capacity at the congregation for all activities, 
Predictors of Congregational HIV Activities

including HIV (B. R. Redacted , 2016). Moreover, having an openly HIV positive person in the congregation likely raises the profile of HIV as a condition to address within the congregation.

Despite these similarities, there were also subtle differences in the factors associated with engagement in each type of HIV activity. For example, prior research suggests that clergy education is positively associated with the existence of HIV activities in their congregations. However, our multivariate logistic regressions of the predictors of the involvement in any HIV activity and specifically HIV prevention activities found a negative association. Upon further analysis, we found in the alternative-specific conditional logistic model that, relative to prevention activities, clergy education is positively associated with providing support to people with HIV, raising awareness about HIV and making donations for HIV activities to other organizations. This result suggests on the one hand that the level of clergy education is an important predictor, but operates differently for prevention vs. other types of HIV activities. A possible reason for this could be related to the types of prevention activities that are common at congregations. Observations from earlier case studies (Redacted et al., 2011) found that, for many congregations, abstinence was the most common prevention activity, and that more educated clergy were less likely to emphasize abstinence over other prevention strategies. The fact that abstinence is a common prevention activity in congregations may also explain why politically conservative congregations were more likely to engage in prevention relative to awareness raising and advocacy.

Consistent with prior research, we found that predominantly African-American congregations were more likely than other congregations to engage in each type of HIV activity. But relative to HIV prevention activities, they are less likely to engage in all other types of HIV activities. This confirms results identified in case studies (Redacted et al., 2011) of congregational HIV activities among African-American congregations and may be related to the timing of involvement in the HIV epidemic among these institutions. Early on, congregations tended to provide care and support (e.g., assistance with activities of daily living, spiritual support around death and dying, etc.) directly to persons with HIV. But African American congregations tended to get involved after the development of Anti-retroviral Therapy (ART), which extended life and reduced morbidity for many HIV positive persons (Oguntibeju, 2012). Thus, the emphasis in congregation programming when African American congregations became more involved may have been less focused on care and support, given less need, and thus prevention activities became more common. We also found that congregations with greater resources (as 
Predictors of Congregational HIV Activities

measured by having a staff person with at least 25 percent of their time dedicated to social service projects) were more likely to provide donations to other organizations to support their HIV activities than to engage in prevention. Having such staff could increase contact with outside organizations, making the congregation leadership aware of opportunities for partnership and/or providing donations to such organizations for their HIV activities. Such staff may also facilitate fundraising within the congregation for these types of donations.

One problem in interpreting these results is that despite the additional information about the different types of HIV activities that congregations offer, some of the broad categories still contain a wide range of potential activities. HIV prevention is particularly problematic. Redacted and colleagues' (Redacted et al., 2011) case studies identified a range of activities that are labeled as prevention despite their different approaches, including HIV education through workshops, distribution of HIV educational materials, abstinence, health fairs, and HIV testing and discussion of condoms. In addition, these case studies identified that the number of congregations engaged in abstinence activities ( 8 of 14 ) was similar to the number engaged in HIV testing and discussions about condoms (6 of 14). The factors that predict involvement in these different prevention approaches may or may not be similar. For example, in our data, we found that conservative congregations and predominantly African American congregations were less likely to engage in other types of HIV activities relative to prevention, but we don't know what their prevention activities involved. Future research could explore the different types of HIV prevention strategies congregations use and how these strategies are associated with various congregational factors. We also found that clergy education was negatively related to prevention. It is not clear whether this is a new finding and that more educated clergy are less likely to pastor congregations with HIV prevention activities, or if it's possible that more educated pastors choos other types of activities, either to avoid controversy within the congregation or because they feel these other types of activities (e.g., supporting people with HIV) are more appropriate or needed. Future studies are needed to understand the prevalence of different congregational HIV prevention activities. Future analyses should also focus on understanding the factors that predict African-American congregations' involvement in different HIV activities given the important disparities around HIV that exist in the African-American community.

These analyses are limited by several factors. We cannot infer causality for any relationships that are found, since the data are cross-sectional. Omitted variable bias may also be a problem. For example, we are 
Predictors of Congregational HIV Activities

only able to measure fairly crude indicators related to stigma, such as allowing openly gay persons to be members; this does not allow for refined measurement of the full continuum of attitudes on which congregations vary (Bluthenthal et al., 2012). Measuring stigma more directly will be important in future analyses of the impact of congregational factors associated with sponsoring HIV activities. Also, not all HIV activities are well planned and executed and there is no information on the quality of these activities. If a large portion of congregational efforts are ineffective, identifying ways to encourage greater development in this area would not be an efficient way to pursue public health goals.

\section{CONCLUSIONS}

Despite the limitations described above, our analyses are innovative in being the first to quantify the various types of HIV activities that exist in congregations and the predictors of these activities among a nationally representative sample of congregations. Although prior literature about congregational HIV interventions tended to focus on HIV activities in general, our findings suggest that there is variability in the factors that predict each type of activity especially.

This better understanding of the prevalence of specific types of activities and the factors associated with them helps inform policy and practice related to community-based HIV prevention and care efforts by identifying factors that facilitate congregational involvement in each specific activity. This work will be of interest to health and social service professionals interested in building effective partnerships with congregations around HIV activities. Over time, the HIV epidemic and resultant prevention and treatment modalities have continued to change, and current prevention efforts focus much more on testing and early treatment to stem new infections - or "treatment as prevention" (Cohen et al., 2011; Cohen et al., 2013; Coleman et al., 2012; Obong'o et al., 2016). Many congregations may find it easier to promote HIV testing and early treatment rather than prevention strategies such as condom use and needle exchange. Such an approach might involve congregations not only serving as trusted venues for rapid HIV testing, but also addressing barriers to care and adherence to treatment such as lack of health insurance, food insecurity, substance use, and housing which all require some degree of partnership with health and social service providers. 
Predictors of Congregational HIV Activities

\section{References}

AIDSVu (www.aidsdvu.org). Emory University, Rollins School of Public Health.

Blank, M. B., Mahmood, M., Fox, J. C., \& Guterbock, T. (2002). Alternative mental health services: The role of the Black church in the south. American Journal of Public Health, 92(10), 1668-1672.

Bluthenthal, R. N., Palar, K., Mendel, P., Kanouse, D. E., Corbin, D. E., \& Redacted (2012). Attitudes and beliefs related to HIVIAIDS in urban religious congregations: Barriers and opportunities for HIV-related interventions. Social Science and Medicine, 74(10), 1520-1527. doi:10.1016/j.socscimed.2012.01.020

Boltri, J. M., Davis-Smith, Y. M., Zayas, L. E., Shellenberger, S., Seale, J. P., Blalock, T. W., \& Mbadinuju, A. (2006). Developing a church-based diabetes prevention program with African Americans: focus group findings. Diabetes Educator, 32(6), 901-909. doi:10.1177/0145721706295010

Campbell, M. K., Hudson, M. A., Resnicow, K., Blakeney, N., Paxton, A., \& Baskin, M. (2007). Church-based health promotion interventions: Evidence and lessons learned. Annual Review of Public Health, 28, 213-234. doi:10.1146/annurev.publhealth.28.021406

Centers for Disease and Control and Prevention. (2010). HIV Among African Americans. Retrieved from Atlanta:

Centers for Disease and Control and Prevention. (2011). HIV in the United States. Retrieved from Atlanta: Division of HIVIAIDS Prevention: http://www.cdc.gov/hiv/resources/factsheets/PDF/us.pdf

Chaves, M. (2004). Congregations in America. Cambridge, MA: Harvard University Press.

Chaves, M., Anderson, S., \& Eagle, A. (2014). National Congregations Study. Cumulative data file and codebook. Durham, North Carolina: Duke University, Department of Solciology.

Chaves, M., \& Anderson, S. L. (2014). Changing American Congregations: Findings from the Third Wave of the National Congregations Study. Journal for the Scientific Study of Religion, 53(4), 676-686. doi:10.1111/jssr.12151

Chaves, M., \& Tsitsos, W. (2001). Congregations and Social Services: What They Do, How They Do It, and with Whom. Nonprofit and Voluntary Sector Quarterly, 30(4), 660-683. doi:10.1177/0899764001304003 
Predictors of Congregational HIV Activities

Chin, J. J., Mantell, J., Weiss, L., Bhagavan, M., \& Luo, X. (2005). Chinese and South Asian religious institutions and HIV prevention in New York City. AIDS Education and Prevention, 17(5), 484-502.

Cohen, M. S., Chen, Y. Q., McCauley, M., Gamble, T., Hosseinipour, M. C., Kumarasamy, N., . . Team, H. S. (2011). Prevention of HIV-1 infection with early antiretroviral therapy. New England Journal of Medicine, 365(6), 493-505. doi:10.1056/NEJMoa1105243

Cohen, M. S., Smith, M. K., Muessig, K. E., Hallett, T. B., Powers, K. A., \& Kashuba, A. D. (2013). Antiretroviral treatment of HIV-1 prevents transmission of HIV-1: where do we go from here? Lancet, 382(9903), 1515-1524. doi:10.1016/S0140-6736(13)61998-4

Coleman, J. D., Lindley, L. L., Annang, L., Saunders, R. P., \& Gaddist, B. (2012). Development of a framework for HIVIAIDS prevention programs in African American churches. AIDS Patient Care and STDS, 26(2), 116-124. doi:10.1089/apc.2011.0163

County Health Rankings. (2017). Our Approach. Retrieved from http://www.countyhealthrankings.org/ourapproach

DeHaven, M. J., Hunter, I. B., Wilder, L., Walton, J. W., \& Berry, J. (2004). Health programs in faith-based organizations: are they effective? American Journal of Public Health, 94(6), 1030-1036.

Redacted, Mendel, P. J., Kanouse, D. E., Bluthenthal, R. N., Castaneda, L. W., Hawes-Dawson, J., . . Oden, C. W. (2010). Learning about urban congregations and HIVIAIDS: Community-based foundations for developing congregational health interventions. Journal of Urban Health, 87(4), 617-630. doi:10.1007/s11524-010-9444-6

Redacted, Mendel, P. J., Palar, K., Kanouse, D. E., Bluthenthal, R. N., Castaneda, L. W., ... Oden, C. W. (2011). Religious congregations' involvement in HIV: A case study approach. AIDS and Behavior, 15(6), 1220-1232.

Francis, S. A., \& Liverpool, J. (2009). A Review of Faith-Based HIV Prevention Programs. J Relig Health, 48(1), 6-15.

Frenk, S. M., \& Trinitapoli, J. (2012). U.S. Congregations' Provision of Programs or Activities for People Living with HIVIAIDS. AIDS and Behavior, 17(5), 1829-1838. doi:10.1007/s10461-012-0145-x 
Predictors of Congregational HIV Activities

Redacted (2011). Black Churches and HIVIAIDS: Factors Influencing Congregations' Responsiveness to Social Issues. Journal for the Scientific Study of Religion, 50(3), 617-630.

Redacted (2016). Network ties and organizational action: Explaining variation in social service provision patterns. Management and Organizational Studies 3(3), 1-20.

Redacted (2016). Trends in addressing social needs: A longitudinal study of congregation-based service provision and political participation. Religions, 7(5). doi:Artn 51

10.3390/Rel7050051

Hernandez, E. I., Burwell, R., \& Smith, J. (2007). A Study of Latino Congregatins in Chicago. Retrieved from Hernández, E. I., Burwell, R., \& Smith, J. (2007). Answering the Call: How Latino Churches Can Respond to the HIVIAIDS Epidemic. Retrieved from Philadelphia: http://www.esperanza.us/atf/cf/\%7BB793CA9CD2B9-4E02-886B-E6DE52E04944\%7D/HIV AIDS Study.pdf

Hicks, K. E., Allen, J. A., \& Wright, E. M. (2005). Building holistic HIVIAIDS responses in African American urban faith communities: a qualitative, multiple case study analysis. Family and Community Health, 28(2), 184-205.

Kaiser Family Foundation. (2006). HIVIAIDS Policy Fact Sheet: Black Americans and HIVIAIDS. Menlo Park, CA: Kaiser Family Foundation.

Leong, P. (2006). Religion, flesh, and blood: Re-creating religious culture in the context of HIVIAIDS. Sociology of Religion, 67(3), 295-311.

Maton, K. I., \& Rappaport, J. (1984). Empowerment in a religious setting: A multivariate investigation. Prevention in Human Services, 3(2-3), 37-72. doi:10.1300/J293v03n02_04

Nohria, N., \& Gulati, R. (1996). Is slack good or bad for innovation? Academy of Management Journal, 39(5), 1245-1264. doi:Doi 10.2307/256998

Obong'o, C. O., Pichon, L. C., Powell, T. W., \& Williams, A. L. (2016). Strengthening partnerships between Black Churches and HIV service providers in the United States. AIDS Care, 1-5. doi:10.1080/09540121.2016.1139666

Oguntibeju, O. O. (2012). Quality of life of people living with HIV and AIDS and antiretroviral therapy. HIVIAIDS (Auckland, N.Z.), 4, 117-124. doi:10.2147/HIV.S32321 
Predictors of Congregational HIV Activities

Rogers, S. J., Doinolngersoll, J., HayesCozier, R., \& Weisfuse, I. (1996). Evaluating HIV prevention community planning. Evaluation and the Health Professions, 19(4), 465-487. doi:Doi

$10.1177 / 016327879601900406$

Royston, P. (2009). Multiple imputation of missing values: Further update of ice, with an emphasis an categorical variables. Stata Journal, 9(3), 466-477.

Rubin, D. B. (1987). Multiple Imputation for Nonresponse in Surveys. Hoboken, NJ: John Wiley \& Sons.

Rubin, R. H., Billingsley, A., \& Caldwell, C. H. (1994). The role of the Black church in working with Blackadolescents. Adolescence, 29(114), 251-266.

Smith, J., Simmons, E., \& Mayer, K. H. (2005). HIVIAIDS and the Black Church: What are the barriers to prevention services? Journal of the National Medical Association, 97(12), 1682-1685.

Tesoriero, J. M., Parisi, D. M., Sampson, S., Foster, J., Klein, S., \& Ellemberg, C. (2000). Faith communities and HIVIAIDS prevention in New York State: results of a statewide survey. Public Health Reports, 115(6), 544-556.

Thomas, S. B., Quinn, S. C., Billingsley, A., \& Caldwell, C. (1994). The characteristics of northern black churches with community health outreach programs. American Journal of Public Health, 84(4), 575.

Tsitsos, W. (2003). Race differences in congregational social service activity. Journal for the Scientific Study of Religion, 42(2), 205-215. doi:Doi 10.1111/1468-5906.00173

Redacted, Redacted, Redacted, Redacted, Kanouse, D. E., Bogart, L. M., \& Redacted (2015). Predictors of the existence of congregational HIV programs: Similarities and differences compared with other health programs. American Journal of Health Promotion, 29(6), e225-235. doi:10.4278/ajhp.130531-QUAN280

Redacted, Palar, K., \& Redacted (2011). Congregation-Based Programs to Address HIVIAIDS: Elements of Successful Implementation. Journal of Urban Health, 88(3), 517-532.

Wuthnow, R. (2004). Saving America? Faith-Based Services and the Future of Civil Society. Princeton, NJ: Princeton UniversityPress. 
Predictors of Congregational HIV Activities

Young, S., Shoptaw, S., Weiss, R., Munjas, B., \& Gorbach, P. (2011). Predictors of Unrecognized HIV Infection Among Poor and Ethnic Men Who Have Sex with Men in Los Angeles. AIDS and Behavior, 15(3), 643649. doi:10.1007/s10461-009-9653-8 
Table I. Summary of predictors by domain

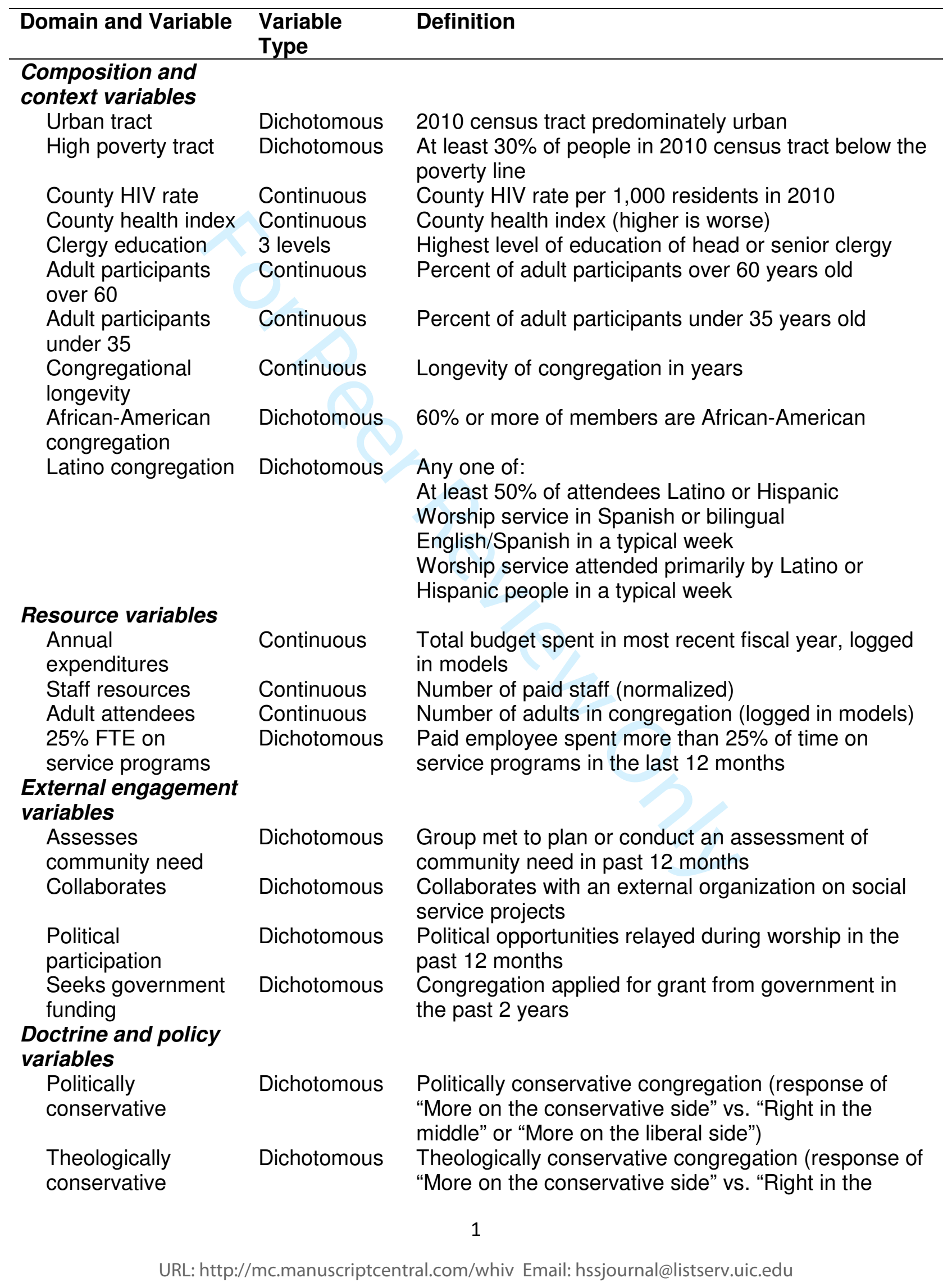


Bible is inerrant Dichotomous Congregation considers the Bible to be the literal and inerrant word of God

Allows gay Dichotomous Congregation allows openly gay couples to be full-

members fledged members

Allows gay leaders Dichotomous Congregation allows openly gay couples to hold volunteer leadership positions

HIV-positive Dichotomous Any regular participant is openly HIV-positive member Any openly gay Dichotomous Any regular participant is openly gay participants 
Table II. Congregation characteristics, weighted to the attendee level. $\mathrm{N}=1,306$

\begin{tabular}{lc}
\hline Variables & Percent \\
\hline Outcomes & \\
Any HIV activities & $26.5 \%$ \\
Prevention activities & $12.3 \%$ \\
Support activities & $11.9 \%$ \\
Awareness activities & $12.3 \%$ \\
Donating & $12.4 \%$ \\
Composition and context variables & \\
Urban tract & $72.5 \%$ \\
High poverty tract & $14.6 \%$ \\
County HIV rate (per 1,000) & $3.2(3.6)^{\mathrm{a}}$ \\
County health index & $-0.27(0.67)$ \\
Clergy education & $11.4 \%$ \\
$\quad$ High school or less & $18.1 \%$ \\
$\quad$ Some college/BA & $70.5 \%$ \\
$\quad$ Graduate degree & $35.0(21.4)$ \\
Adult participants over 60 & $27.7(16.5)$ \\
Adult participants under 35 & $77.1(54.7)$ \\
Congregational longevity & $14.9 \%$ \\
African-American congregation & $20.9 \%$ \\
Latino congregation & \\
Resource variables & $\$ 402,291$ \\
Median annual expenditures & 5.5 \\
Median full-time paid staff & 300 \\
Median number of adult attendees & $21.7 \%$ \\
25\% FTE on service programs & $67.3 \%$ \\
External engagement variables & $74.0 \%$ \\
Assesses community need & $23.7 \%$ \\
Collaborates & $9.1 \%$ \\
Political participation & $53.3 \%$ \\
Seeks government funding & $59.7 \%$ \\
Doctrine and policy variables & \\
Politically conservative & \\
Theologically conservative & \\
\hline & \\
\hline
\end{tabular}




\begin{tabular}{ll}
\hline Bible is inerrant & $68.7 \%$ \\
Allows gay members & $50.6 \%$ \\
Allows gay leaders & $26.7 \%$ \\
HIV-positive member & $11.6 \%$ \\
Any openly gay participants & $31.3 \%$ \\
\hline
\end{tabular}

${ }^{a}$ Standard deviations of continuous variables are listed in parentheses 
Table III. Estimated odds ratios from multivariate regression of any HIV activity and each type of HIV activity (prevention, support, awareness, and donation), weighted to the attendee level. $\mathrm{N}=1,306$ for all models.

\begin{tabular}{|c|c|c|c|c|c|}
\hline & $\begin{array}{l}\text { Any HIV } \\
\text { Activity }\end{array}$ & $\begin{array}{l}\text { Prevention } \\
\text { Activity }\end{array}$ & $\begin{array}{l}\text { Support } \\
\text { Activity }\end{array}$ & $\begin{array}{l}\text { Awareness } \\
\text { Activity }\end{array}$ & Donating \\
\hline \multicolumn{6}{|l|}{$\begin{array}{l}\text { Composition and } \\
\text { context }\end{array}$} \\
\hline Urban tract & $\begin{array}{l}0.95 \\
{[0.57,1.58]}\end{array}$ & $0.84[0.37,1.90]$ & $\begin{array}{l}0.89 \\
{[0.46,1.72]}\end{array}$ & $\begin{array}{l}0.88 \\
{[0.46,1.70]}\end{array}$ & $\begin{array}{l}1.38 \\
{[0.74,2.57]}\end{array}$ \\
\hline $\begin{array}{l}\text { High poverty } \\
\text { tract }\end{array}$ & $\begin{array}{l}1.09 \\
{[0.66,1.81]}\end{array}$ & $1.26[0.63,2.49]$ & $\begin{array}{l}1.18 \\
{[0.63,2.22]}\end{array}$ & $\begin{array}{l}1.02 \\
{[0.53,1.96]}\end{array}$ & $\begin{array}{l}0.74 \\
{[0.37,1.48]}\end{array}$ \\
\hline County HIV rate & $\begin{array}{l}1.04 \\
{[0.99,1.09]}\end{array}$ & $1.02[0.96,1.08]$ & $\begin{array}{l}1.02 \\
{[0.96,1.08]}\end{array}$ & $\begin{array}{l}1.04 \\
{[0.99,1.11]}\end{array}$ & $\begin{array}{l}0.96 \\
{[0.90,1.03]}\end{array}$ \\
\hline $\begin{array}{l}\text { County health } \\
\text { index }\end{array}$ & $\begin{array}{l}1.07 \\
{[0.79,1.45]}\end{array}$ & $1.20[0.79,1.83]$ & $\begin{array}{l}0.96 \\
{[0.63,1.45]}\end{array}$ & $\begin{array}{l}0.97 \\
{[0.68,1.39]}\end{array}$ & $\begin{array}{l}1.06 \\
{[0.73,1.56]}\end{array}$ \\
\hline \multicolumn{6}{|l|}{$\begin{array}{l}\text { Clergy } \\
\text { education }\end{array}$} \\
\hline $\begin{array}{l}\text { High school or } \\
\text { less [ref] }\end{array}$ & 1.00 & 100 & 1.00 & 1.00 & 1.00 \\
\hline $\begin{array}{l}\text { Some } \\
\text { college/BA } \\
\text { Graduate } \\
\text { degree }\end{array}$ & $\begin{array}{l}0.42 \\
{[0.21,0.85]^{*}} \\
0.72 \\
{[0.40,1.31]}\end{array}$ & $\begin{array}{l}0.24 \\
{[0.10,0.57]^{* *}} \\
0.43 \\
{[0.21,0.88]^{*}}\end{array}$ & $\begin{array}{l}1.10 \\
{[0.43,2.82]} \\
1.03 \\
{[0.47,2.29]}\end{array}$ & $\begin{array}{l}0.72 \\
{[0.27,1.91]} \\
1.23 \\
{[0.52,2.92]}\end{array}$ & $\begin{array}{l}0.91 \\
{[0.34,2.40]} \\
1.01 \\
{[0.46,2.21]}\end{array}$ \\
\hline $\begin{array}{l}\text { Adult } \\
\text { participants over } \\
60\end{array}$ & $\begin{array}{l}1.00 \\
{[0.99,1.01]}\end{array}$ & $1.00[0.99,1.02]$ & $\begin{array}{l}1.00 \\
{[0.99,1.01]}\end{array}$ & $\begin{array}{l}1.00 \\
{[0.98,1.01]}\end{array}$ & $\begin{array}{l}1.00 \\
{[0.99,1.02]}\end{array}$ \\
\hline $\begin{array}{l}\text { Adult } \\
\text { participants } \\
\text { under } 35\end{array}$ & $\begin{array}{l}1.01 \\
{[0.99,1.02]}\end{array}$ & $1.01[0.99,1.02]$ & $\begin{array}{l}1.01 \\
{[1.00,1.03]}\end{array}$ & $\begin{array}{l}1.00 \\
{[0.98,1.01]}\end{array}$ & $\begin{array}{l}1.00 \\
{[0.98,1.02]}\end{array}$ \\
\hline $\begin{array}{l}\text { Congregational } \\
\text { longevity }\end{array}$ & $\begin{array}{l}1.00 \\
{[1.00,1.00]}\end{array}$ & $1.00[0.99,1.01]$ & $\begin{array}{l}1.00 \\
{[1.00,1.01]}\end{array}$ & $\begin{array}{l}1.00 \\
{[0.99,1.00]}\end{array}$ & $\begin{array}{l}1.00 \\
{[1.00,1.00]}\end{array}$ \\
\hline African- & 2.65 & 5.79 & 2.81 & 3.66 & 3.46 \\
\hline American & {$[1.59,4.43]^{\star \star *}$} & {$[2.96,11.34]^{* * *}$} & {$[1.49,5.30]^{* *}$} & {$[1.92,6.97]^{\star \star *}$} & {$[1.83,6.55]^{\star * *}$} \\
\hline Latino & $\begin{array}{l}0.95 \\
{[0.58,1.54]}\end{array}$ & $1.42[0.74,2.72]$ & $\begin{array}{l}1.18 \\
{[0.66,2.10]}\end{array}$ & $\begin{array}{l}0.67 \\
{[0.36,1.26]}\end{array}$ & $\begin{array}{l}1.34 \\
{[0.76,2.35]}\end{array}$ \\
\hline \multicolumn{6}{|l|}{ Resources } \\
\hline $\begin{array}{l}\text { Annual } \\
\text { expenditures } \\
\text { (logged) }\end{array}$ & $\begin{array}{l}1.03 \\
{[0.90,1.18]}\end{array}$ & $1.14[0.90,1.44]$ & $\begin{array}{l}1.02 \\
{[0.86,1.22]}\end{array}$ & $\begin{array}{l}1.01 \\
{[0.80,1.26]}\end{array}$ & $\begin{array}{l}1.02 \\
{[0.84,1.24]}\end{array}$ \\
\hline $\begin{array}{l}\text { Staff resources } \\
\text { (normalized) } \\
\text { Adult attendees } \\
\text { (logged) }\end{array}$ & $\begin{array}{l}1.08 \\
{[0.89,1.31]} \\
1.19 \\
{[0.99,1.44]}\end{array}$ & $1.12[0.86,1.45]$ & $\begin{array}{l}1.16 \\
{[0.93,1.43]} \\
1.22 \\
{[0.96,1.54]}\end{array}$ & $\begin{array}{l}0.75 \\
{[0.57,0.97]^{\star}} \\
1.33 \\
{[1.03,1.73]^{\star}}\end{array}$ & $\begin{array}{l}1.12 \\
{[0.93,1.36]} \\
1.25 \\
{[1.00,1.57]^{*}}\end{array}$ \\
\hline $\begin{array}{l}25 \% \text { FTE on } \\
\text { service } \\
\text { programs } \\
\text { External } \\
\text { Engagement }\end{array}$ & $\begin{array}{l}2.20 \\
{[1.47,3.27]^{\star \star *}}\end{array}$ & $\begin{array}{l}2.61 \\
{[1.57,4.34]^{\star * *}}\end{array}$ & $\begin{array}{l}2.05 \\
{[1.26,3.35]^{\star *}}\end{array}$ & $\begin{array}{l}2.54 \\
{[1.53,4.22]^{\star \star *}}\end{array}$ & $\begin{array}{l}1.84 \\
{[1.16,2.93]^{*}}\end{array}$ \\
\hline $\begin{array}{l}\text { Assesses } \\
\text { community need }\end{array}$ & $\begin{array}{l}2.11 \\
{[1.39,3.20]^{* * *}}\end{array}$ & $\begin{array}{l}2.41 \\
{[1.25,4.65]^{* *}}\end{array}$ & $\begin{array}{l}2.16 \\
{[1.18,3.93]^{*}}\end{array}$ & $\begin{array}{l}1.47 \\
{[0.84,2.56]}\end{array}$ & $\begin{array}{l}1.39 \\
{[0.80,2.42]}\end{array}$ \\
\hline Collaborates & $\begin{array}{l}1.31 \\
{[0.84,2.04]}\end{array}$ & $1.78[0.89,3.56]$ & $\begin{array}{l}0.91 \\
{[0.52,1.58]}\end{array}$ & $\begin{array}{l}1.40 \\
{[0.80,2.45]}\end{array}$ & $\begin{array}{l}1.51 \\
{[0.89,2.56]}\end{array}$ \\
\hline Political & 1.53 & $1.52[0.89,2.59]$ & 1.01 & 2.14 & 1.27 \\
\hline
\end{tabular}




\begin{tabular}{|c|c|c|c|c|c|}
\hline participation & {$[1.02,2.31]^{*}$} & & {$[0.62,1.64]$} & {$[1.29,3.53]^{\star *}$} & {$[0.79,2.05]$} \\
\hline $\begin{array}{l}\text { Seeks } \\
\text { government } \\
\text { funding }\end{array}$ & $\begin{array}{l}0.89 \\
{[0.50,1.60]}\end{array}$ & $1.09[0.58,2.03]$ & $\begin{array}{l}1.24 \\
{[0.63,2.41]}\end{array}$ & $\begin{array}{l}0.78 \\
{[0.39,1.56]}\end{array}$ & $\begin{array}{l}1.10 \\
{[0.56,2.14]}\end{array}$ \\
\hline \multicolumn{6}{|l|}{$\begin{array}{l}\text { Doctrine and } \\
\text { Policy }\end{array}$} \\
\hline $\begin{array}{l}\text { Politically } \\
\text { conservative }\end{array}$ & $\begin{array}{l}0.62 \\
{[0.41,0.92]^{*}}\end{array}$ & $0.75[0.42,1.32]$ & $\begin{array}{l}0.80 \\
{[0.46,1.36]}\end{array}$ & $\begin{array}{l}0.43 \\
{[0.25,0.75]^{\star *}}\end{array}$ & $\begin{array}{l}0.82 \\
{[0.49,1.37]}\end{array}$ \\
\hline $\begin{array}{l}\text { Theologically } \\
\text { conservative }\end{array}$ & $\begin{array}{l}0.97 \\
{[0.64,1.47]}\end{array}$ & $1.22[0.69,2.17]$ & $\begin{array}{l}1.07 \\
{[0.63,1.82]}\end{array}$ & $\begin{array}{l}0.79 \\
{[0.46,1.35]}\end{array}$ & $\begin{array}{l}0.78 \\
{[0.46,1.31]}\end{array}$ \\
\hline Bible is inerrant & $\begin{array}{l}0.89 \\
{[0.56,1.40]}\end{array}$ & $0.96[0.50,1.84]$ & $\begin{array}{l}1.40 \\
{[0.77,2.56]}\end{array}$ & $\begin{array}{l}1.10 \\
{[0.61,2.01]}\end{array}$ & $\begin{array}{l}0.99 \\
{[0.57,1.71]}\end{array}$ \\
\hline $\begin{array}{l}\text { Allows gay } \\
\text { members }\end{array}$ & $\begin{array}{l}1.08 \\
{[0.68,1.71]}\end{array}$ & $1.29[0.70,2.39]$ & $\begin{array}{l}1.40 \\
{[0.75,2.58]}\end{array}$ & $\begin{array}{l}0.94 \\
{[0.48,1.82]}\end{array}$ & $\begin{array}{l}1.30 \\
{[0.71,2.38]}\end{array}$ \\
\hline $\begin{array}{l}\text { Allows gay } \\
\text { leaders }\end{array}$ & $\begin{array}{l}1.47 \\
{[0.87,2.47]}\end{array}$ & $0.80[0.39,1.63]$ & $\begin{array}{l}1.76 \\
{[0.92,3.35]}\end{array}$ & $\begin{array}{l}1.34 \\
{[0.66,2.71]}\end{array}$ & $\begin{array}{l}1.51 \\
{[0.80,2.87]}\end{array}$ \\
\hline $\begin{array}{l}\text { Has openly HIV- } \\
\text { positive member }\end{array}$ & $\begin{array}{l}2.50 \\
{[1.53,4.11]^{\star * *}}\end{array}$ & $\begin{array}{l}2.19 \\
1125383]^{* *}\end{array}$ & $\begin{array}{l}3.13 \\
{[179546]^{\star * *}}\end{array}$ & $\begin{array}{l}2.20 \\
{[121402]^{\star *}}\end{array}$ & 1.92 \\
\hline $\begin{array}{l}\text { Any openly gay } \\
\text { participants }\end{array}$ & $\begin{array}{l}1.00 \\
{[0.63,1.59]}\end{array}$ & $0.99[0.52,1.90]$ & $\begin{array}{l}1.37 \\
{[0.78,2.39]}\end{array}$ & $\begin{array}{l}1.58 \\
{[0.86,2.90]}\end{array}$ & $\begin{array}{l}1.08 \\
{[0.59,1.99]}\end{array}$ \\
\hline
\end{tabular}


Table IV. Estimated odds ratios from alternative-specific conditional logistic regression for type of HIV activity among congregations with any activity, weighted to the attendee level. $\mathrm{N}=344$ congregations.

\begin{tabular}{|c|c|c|c|c|}
\hline & Support $^{\mathrm{a}}$ & Awareness $^{a}$ & Donating $^{a}$ & $\begin{array}{l}\text { Joint } p- \\
\text { value, } d f=3\end{array}$ \\
\hline \multicolumn{5}{|l|}{ Composition and context } \\
\hline County HIV rate & $0.98[0.89,1.08]$ & $1.03[0.94,1.13]$ & $0.92[0.82,1.03]$ & 0.1939 \\
\hline \multicolumn{5}{|l|}{ Clergy education } \\
\hline \multicolumn{5}{|l|}{$\begin{array}{l}\text { High school or less } \\
\text { [ref] }\end{array}$} \\
\hline Some college/BA & $11.98[1.85,77.49]^{\star *}$ & $4.69[0.86,25.55]$ & $10.23[1.55,67.43]^{*}$ & 0.0463 \\
\hline Graduate degree & $4.86[1.00,23.57]^{*}$ & $5.44[1.33,22.18]^{*}$ & $6.17[1.36,27.99]^{*}$ & 0.0512 \\
\hline Adult participants $<35$ & $1.00[0.97,1.03]$ & $0.99[0.97,1.01]$ & $0.97[0.94,1.01]$ & 0.0797 \\
\hline African-American & $0.18[0.06,0.49]^{* * *}$ & $0.29[0.11,0.80]^{*}$ & $0.19[0.06,0.60]^{* *}$ & 0.0055 \\
\hline \multicolumn{5}{|l|}{ Resources } \\
\hline $\begin{array}{l}\text { Staff resources } \\
\text { (normalized) }\end{array}$ & $1.27[0.93,1.74]$ & $0.77[0.58,1.02]$ & $1.27[1.00,1.62]^{*}$ & 0.0033 \\
\hline \multicolumn{5}{|l|}{ External Engagement } \\
\hline Collaborates & $0.28[0.07,1.04]$ & $0.73[0.22,2.44]$ & $0.70[0.19,2.55]$ & 0.1106 \\
\hline \multicolumn{5}{|l|}{ Doctrine and Policy } \\
\hline Politically conservative & $0.57[0.23,1.44]$ & $0.30[0.13,0.72]^{\star *}$ & $0.58[0.25,1.37]$ & 0.0621 \\
\hline HIV-positive member & $2.42[0.93,6.32]$ & $1.62[0.60,4.37]$ & $0.94[0.32,2.73]$ & 0.1229 \\
\hline
\end{tabular}

